\title{
EFFECTS OF IRRIGATION, ORGANIC AND INORGANIC NUTRIENT SOURCES ON THE GROWTH, YIELD AND SOIL FERTILITY STATUS WITH RICE-RICE CROPPING
}

\author{
M.A. Khan ${ }^{1}$, S.A. Shampa ${ }^{1}$, P.K. Biswas ${ }^{2}$ and M.B. Hossain ${ }^{3}$ \\ ${ }^{1}$ Department of Soil Science, ${ }^{2}$ Department of Agronomy, Sher-e-Bangla Agricultural University, \\ Dhaka-1207, Bangladesh \\ 3Bangladesh Agricultural Research Council, Farmgate, Dhaka-1207, Bangladesh \\ Corresponding E-mail: makhan_sau@ymail.com
}

(Received: 07 March 2021, Accepted: 26 March 2021)

Keywords: Irrigation, fertilizer, manure, rice yield, soil fertility

\begin{abstract}
Continuous cultivation of highly exhaustive cropping sequence in most of the irrigated fertile lands has resulted in the decline of soil physico-chemical condition in general and particularly soil organic matter (SOM) content. The experiment was laid out inasplit- plot design with irrigation $\left(\mathrm{I}_{1}\right.$ : traditional irrigation i.e. continuous flooding, $\mathrm{I}_{2}$ : saturated condition, $\mathrm{I}_{3}$ : Alternate wetting and drying) in main plots and fertilizers treatments: $\mathrm{T}_{0}=$ Control, $\mathrm{T}_{1}=100 \%$ (Recommended dose of chemical fertilizer), $\mathrm{T}_{2}=50 \% \mathrm{RDCF}+5$ ton cowdung ha- ${ }^{1}, \mathrm{~T}_{3}=70 \% \mathrm{RDCF}+3$ ton cowdung ha ${ }^{-1}, \mathrm{~T}_{4}=50 \% \mathrm{RDCF}+5$ ton compost ha ${ }^{-1}, \mathrm{~T}_{5}=70 \% \mathrm{RDCF}+3$ ton compost ha-1 $\mathrm{T}_{6}=50 \% \mathrm{RDCF}+3.5$ ton poultry manure ha ${ }^{-1}, \mathrm{~T}_{7}=70 \% \mathrm{RDCF}+$ 2.1 ton poultry manure ha ${ }^{-1}$ to the sub - plots. The rice yields were not significantly affected by different irrigation but higher grain yields were obtained in continuous flooded irrigation. The treatment $\mathrm{T}_{7}$ gave higher Boro and $\mathrm{T}$. Aman rice yields. The higher Boro rice grain yields were obtained from $\mathrm{I}_{1} \mathrm{~T}_{7}(70 \% \mathrm{RDCF}+2.1$ ton poultry manure ha- ${ }^{-1}$ with continuous flooded irrigation) followed by $\mathrm{I}_{3} \mathrm{~T}_{7}$ (alternate wetting and drying $+70 \%$ RDCF +2.1 ton poultry manure ha $\left.{ }^{-1}\right)$. The $100 \%$ RDCF was applied to T. Aman rice resulted residual effects of fertilizer and the higher T. Aman rice yields were recorded in $\mathrm{I}_{2} \mathrm{~T}_{2}$ (saturated condition $+50 \% \mathrm{RDCF}+3$ ton cowdungha $^{-1}$ ) followed by $\mathrm{I}_{2} \mathrm{~T}_{3}$ (saturated condition $+50 \%$ RDCF +3 ton cowdungha $^{-1}$ ) treatment combinations due to more residual effects of inorganic plus manure application during Boro rice cropping. The highest organic matter level was found in post-harvest soils where inorganic fertilizer plus cowdung were used and soil $\mathrm{pH}$ increased by using poultry manure. The higher levels of available $\mathrm{P}$ and $\mathrm{K}$ concentrations were observed in the post experiment soils where fertilizer and manure were applied.
\end{abstract}

\section{Introduction}

Rice-rice is the most important cropping system in Bangladesh. Continuous cultivation of this highly exhaustive cropping sequence in most of the irrigated fertile lands has resulted in the decline of soil physico-chemical condition in general and particularly soil organic matter (SOM) content. Organic matter decomposition, nutrient mineralization, leaching and efficiency of fertilizer and manures in rice field are greatly affected by the soil moisture level. The yield of rice is low in Bangladesh than in the other rice growing countries like South Korea and Japan (FAO, 1999). Organic and chemical fertilizers are applied for higher yield and improvement of soil fertility and physico-chemical properties. More nutrients are leached out from soil when more 
irrigation water is added during Boro rice growing period. Moisture levels affect the organic matter accumulation and mineralization. Yang et al. (2004) reported that application of chemical fertilizers with farmyard manure or wheat or rice straw in alternate wetting and drying condition increased $\mathrm{N}, \mathrm{P}$, \& $\mathrm{K}$ uptake by rice plants.

Organic manure can supply a good amount of plant nutrients thus can contribute to crop yields. The integrated approach by using the organic and inorganic sources of nutrients helps to improve the efficiency of nutrients. Water input can be reduced by reducing ponded water depths to soil saturation or by alternate wetting/drying. Increasing water scarcity necessitates the development of irrigated rice systems that require less water than traditional flooded rice. In irrigated aerobic rice systems, rice grows in non-flooded and saturated irrigation. The present research work was, therefore, undertaken to find out the effect of chemical fertilizers and organic manure on the productivity and fertility and nutrient availability in Boro-T. Aman rice cropping pattern.

\section{Materials and Methods}

\section{Field Characteristics}

The experiment was conducted in the field of experimental farm at Sher-e-Bangla Agricultural University (SAU), Dhaka during January, 2012 to December, 2014. The area belongs to the Tejgaon soil series of Madhupur Tract (AEZ 28) having $28^{\circ} 74^{\prime} \mathrm{N}$ latitude and $90^{\circ} 35^{\prime} \mathrm{E}$ longitude with an elevation of 8.2 meter from sea level. The soil of the experimental field classified as Deep Red Brown Terrace Soils in Bangladesh soil classification system (UNDP and FAO, 1988). The soil is a silt loam with $6.4 \mathrm{pH}, 1.12 \%$ organic matter (Walkley and Black, 1975), 0.08\% total N (Micro Kjeldahl method; Bremner and Mulvaney, 1982), $12.0 \mu \mathrm{g} \mathrm{g}^{-1}$ available P (0.5M $\mathrm{NaHCO}_{3}$ extractable; Olsen and Sommers, 1982) and $22.5 \mu \mathrm{g} \mathrm{g}^{-1}$ exchangeable $\mathrm{K}\left(1 \mathrm{MNH}_{4} \mathrm{OAc}\right.$ extractable; Page et al., 1982).

\section{Experimental design and treatment}

The experiment was laid out in a split plot design assigning irrigations to the main plots and fertilizer treatments to the sub-plots with three replications. Three Irrigation treatments $\left(I_{1}=\right.$ Continuous flooding (3-4 cm water), $\mathrm{I}_{2}=$ saturated condition (disappearance of water on the surface) and $\mathrm{I}_{3}$ : Alternate wetting and drying) and eight fertilizer treatments $\mathrm{T}_{0}$ : Control, $\mathrm{T}_{1}$ : $100 \%$ Recommended dose of chemical fertilizer (RDCF), $\mathrm{T}_{2}: 50 \% \mathrm{RDCF}+5$ tha $^{-1}$ cowdung, $\mathrm{T}_{3}$ : $70 \%$ RDCF +3 tha $^{-1}$ cowdung, $\mathrm{T}_{4}: 50 \% \mathrm{RDCF}+5$ tha $^{-1}$ compost, $\mathrm{T}_{5}: 70 \% \mathrm{RDCF}+3$ tha $^{-1}$ compost, $\mathrm{T}_{6}: 50 \% \mathrm{RDCF}+3.5$ tha $^{-1}$ poultry manure, $\mathrm{T}_{7}: 70 \% \mathrm{RDCF}+2.1$ tha $^{-1}$ poultry manure were applied in the experiment during Boro rice cultivation.

\section{Field Experiment}

The land was leveled and the experimental plot was partitioned into the unit plots. Treatment wise cowdung, compost, and poultry manures were applied before four days of final land preparation. There were $1.46 \% \mathrm{~N}, 0.29 \% \mathrm{P}, 0.74 \% \mathrm{~K}$ in cowdung; $2.2 \% \mathrm{~N}, 1.99 \% \mathrm{P}, 0.82 \%$ $\mathrm{K}$ in poultry manure and $1.49 \% \mathrm{~N}, 0.28 \% \mathrm{P}, 1.60 \%$ in water hyacinth compost. TSP, MoP, gypsum, zinc sulphate and one third urea were applied during final land preparation. The remaining one third urea was applied at 30 DAT and another one third at 55 DAT. The fertilizer and manures were mixed in the soils of the plots. The first crop boro rice var. BRRI dhan29 was transplanted during first week of January, 2012 and second crop T. Aman rice (var. BRRI dhan32) was transplanted in July 2012. The 35-day old seedlings for Boro rice (dry season rice) and T. Aman (Wet season rice) were transplanted with a spacing of $20 \mathrm{~cm} \times 20 \mathrm{~cm}$. Intercultural operations were done whenever required. 
After harvest of Boro rice, T. Aman rice was transplanted and grown in rainfed condition without any manure application in soil but recommended dose $\left(\mathrm{N}_{100} \mathrm{P}_{15} \mathrm{~K}_{45} \mathrm{~S}_{12} \mathrm{Zn}_{2}\right)$ was applied. Supplemented irrigation was applied as per irrigation treatments during $\mathrm{T}$. Aman growing period. The yield and yield parameters were recorded for each crop. Similarly, third crop Boro rice (2013), fourth crop T. Aman rice (2013) and fifth crop Boro rice (2014) were grown in the same plots with the application of similar fertilizer and irrigation treatments. After harvest of fifth crop, treatment wise post- experimental soils were collected from $0-15 \mathrm{~cm}$ depth and analyzed for $\mathrm{N}, \mathrm{P}, \mathrm{K}, \mathrm{pH}$ and soil organic matter content by using standard methods.

\section{Soil analysis:}

Soil pH was measured by glass electrode $\mathrm{pH}$ meter using soil-water ratio 1:2.5 (McLean, 1982). Organic matter content was estimated by wet oxidation method (Walkley and Black, 1975). The total $\mathrm{N}$ contents in soil were determined by micro-Kjeldahl method (Bramner and Mulvaney, 1982). The soil P (Olsen and Sommers, 1982) and K (Page et al.,1982) were determined by using spectrophotometer and flame photometer, respectively.

\section{Statistical analysis}

The data obtained for different parameters were statistically analyzed and significance of the difference among the treatment means was estimated by the Duncan's Multiple Range Test (DMRT) at 5\% level of probability.

\section{Results and Discussion}

\section{Effects of irrigation, fertilizer and manure (Boro rice)}

The number of effective tillers hill ${ }^{-1}$ was significantly influenced by irrigation in first crop Boro rice and the highest number of effective tillers hill ${ }^{-1}$ was found in continuous flooded condition $\left(\mathrm{I}_{1}\right)$ and lowest in $\mathrm{I}_{3}$ (alternate wetting and drying) (Table 1). Higher yields of first and third Boro rice crops were found in continuous flooded condition which was closely similar to other irrigation treatments (Table 1).

Table 1. Effects of irrigation on the effective tillers hill ${ }^{-1}$, grain and straw yield of first (Boro), second (T. Aman) and third (Boro) rice crops

\begin{tabular}{|c|c|c|c|c|c|c|c|c|c|}
\hline \multirow[t]{3}{*}{ Treatments } & \multicolumn{3}{|c|}{$\begin{array}{c}\text { Number of effective } \\
\text { tillers hill }-1\end{array}$} & \multicolumn{3}{|c|}{$\begin{array}{l}\text { Straw yield } \\
\left(\mathrm{t} \mathrm{ha}^{-1}\right)\end{array}$} & \multicolumn{3}{|c|}{$\begin{array}{l}\text { Grain yield } \\
\left(\mathrm{t} \mathrm{ha}^{-1}\right)\end{array}$} \\
\hline & $1^{\text {st }}$ & $2^{\text {nd }}$ & $3^{\text {rd }}$ & $1^{\text {st }}$ & $2^{\text {nd }}$ & $3^{\text {rd }}$ & $1^{\text {st }}$ & $2^{\text {nd }}$ & $3^{\text {rd }}$ \\
\hline & crop & crop & crop & crop & crop & crop & crop & crop & crop \\
\hline $\mathrm{I}_{1}$ & $13.8 \mathrm{a}$ & 7.15 & 12.52 & 7.07 & 5.98 & 7.02 & 7.06 & 4.37 & 6.38 \\
\hline $\mathrm{I}_{2}$ & $11.3 b$ & 7.27 & 12.89 & 7.08 & 6.53 & 6.81 & 6.94 & 4.81 & 6.05 \\
\hline $\mathrm{I}_{3}$ & $12.6 \mathrm{ab}$ & 6.94 & 13.03 & 6.82 & 6.52 & 6.81 & 6.82 & 4.58 & 6.19 \\
\hline
\end{tabular}

$\mathrm{I}_{1}=$ Continuous flooded; $\mathrm{I}_{2}=$ Saturated condition; $\mathrm{I}_{3}=$ Alternate wetting and drying

In a column figures having similar letter(s) do not differ significantly whereas figures with dissimilar letter(s) differ significantly as per DMRT

Among the different fertilizer treatments, $T_{3}$ showed maximum number of effective tillers hill- 1 (13.9) in first crop Boro rice which was statistically similar to $\mathrm{T}_{7}(70 \% \mathrm{RDCF}+2.1$ ton poultry manure ha-1) treatment. In first crop, $\mathrm{T}_{7}$ showed the maximum plant height $(89.67 \mathrm{~cm})$ which was statistically similar to all other treatments except $T_{0}$ (control). In second crop ( $T$. Aman rice), the residual effect of $\mathrm{T}_{7}$ and renewal application of chemical fertilizer showed the highest number (7.6) of effective tillers hill ${ }^{-1}$. Treatment $T_{4}$ followed by $T_{3}$ showed the maximum plant height $(124.9 \mathrm{~cm})$ and panicle length $(26.06 \mathrm{~cm})$ which was statistically similar to all fertilizer 
treatments except $T_{0}$. In the third crop Boro rice, the highest number of effective tillers hill ${ }^{-1}$ (14.1) was found in $T_{7}$ treatment and higher plant height, panicle lengths and number of filled grains panicle ${ }^{-1}$ were found in organic plus inorganic treatments (Table 2). The lowest number of effective tillers hill ${ }^{-1}$, plant height, and filled grains panicle ${ }^{-1}$ were observed in $\mathrm{T}_{0}$ treatment.

Different fertilizer treatments showed significant variations in respect of grain and straw yields in first, second and third rice crops (Table 3). The highest straw yield of first crop was obtained in $\mathrm{T}_{3}$ treatment which was statistically similar to $\mathrm{T}_{4}, \mathrm{~T}_{5}$ and $\mathrm{T}_{7}$ and the lowest straw yield was obtained in $\mathrm{T}_{0}$ treatment. The highest grain yield $\left(7.47 \mathrm{t} \mathrm{ha}^{-1}\right)$ of first crop was observed in the $T_{7}$ treatment which was statistically similar with the $T_{1}, T_{3}, T_{4}$ and $T_{5}$ and the lowest grain yield (5.02 $\mathrm{t} \mathrm{ha}^{-1}$ ) was observed with $\mathrm{T}_{0}$ treatment. The highest straw yield of second crop (6.78 $\mathrm{t} \mathrm{ha}^{-1}$ ) was obtained in $\mathrm{T}_{2}$ treatment which was statistically similar to all other treatments except $\mathrm{T}_{0}$. The highest grain yield of second crop was observed in the $\mathrm{T}_{7}$ treatment which was statistically similar to all other treatment except $\mathrm{T}_{0}$ (control and the lowest grain yield $\left(3.79\right.$ tha $^{-1}$ ) was observed with $T_{0}$ where no fertilizer was applied. The highest straw yield of third crop (7.72 $\left.t \mathrm{ha}^{-1}\right)$ was obtained in $\mathrm{T}_{1}(100 \% \mathrm{RDCF})$ treatment which was statistically similar to $\mathrm{T}_{3}, \mathrm{~T}_{5} . \mathrm{T}_{6}$ and $T_{7}$ treatments and the lowest straw yield was obtained in $T_{0}$ treatment. The highest grain yield of third crop was observed in the $T_{1}$ and $T_{7}$ treatments and the lowest grain yield $(5.02 \mathrm{t}$ $\mathrm{ha}^{-1}$ ) was observed with $\mathrm{T}_{0}$ where no fertilizer was applied.

Table 2. Effects of nutrient sources on the effective tillers, plant height and panicle length of first (Boro), second (T. Aman) and third (Boro) rice crops

\begin{tabular}{ccccccccc}
\hline \multirow{2}{*}{ Treatments } & \multicolumn{3}{c}{$\begin{array}{c}\text { Number of effective tillers } \\
\text { hill-1 }\end{array}$} & \multicolumn{3}{c}{$\begin{array}{c}\text { Plant height } \\
\text { (cm) }\end{array}$} & \multicolumn{3}{c}{$\begin{array}{c}\text { Panicle length } \\
\text { (cm) }\end{array}$} \\
\cline { 2 - 9 } & $\mathbf{1}^{\text {st }}$ crop & $\mathbf{2}^{\text {nd }}$ crop & 3 $^{\text {rd }}$ crop & $\mathbf{1}^{\text {st }}$ crop & 2 $^{\text {nd }}$ crop & $3^{\text {rd }}$ crop & $2^{\text {nd }}$ crop & $3^{\text {rd }}$ crop \\
\hline $\mathrm{T}_{0}$ & $11.8 \mathrm{c}$ & 6.77 & $10.53 \mathrm{c}$ & $77.89 \mathrm{~b}$ & $105.79 \mathrm{~b}$ & $73.02 \mathrm{~b}$ & $23.36 \mathrm{~b}$ & $22.47 \mathrm{c}$ \\
$\mathrm{T}_{1}$ & $13.6 \mathrm{ab}$ & 7.31 & $13.87 \mathrm{a}$ & $89.33 \mathrm{a}$ & $123.34 \mathrm{a}$ & $85.57 \mathrm{a}$ & $24.70 \mathrm{ab}$ & $25.04 \mathrm{ab}$ \\
$\mathrm{T}_{2}$ & $12.3 \mathrm{abc}$ & 6.76 & $11.13 \mathrm{bc}$ & $85.55 \mathrm{a}$ & $124.44 \mathrm{a}$ & $86.46 \mathrm{a}$ & $26.51 \mathrm{a}$ & $24.57 \mathrm{ab}$ \\
$\mathrm{T}_{3}$ & $13.9 \mathrm{a}$ & 7.27 & $13.22 \mathrm{a}$ & $87.55 \mathrm{a}$ & $122.65 \mathrm{a}$ & $86.57 \mathrm{a}$ & $26.06 \mathrm{a}$ & $24.74 \mathrm{ab}$ \\
$\mathrm{T}_{4}$ & $12.8 \mathrm{abc}$ & 7.36 & $12.73 \mathrm{ab}$ & $86.88 \mathrm{a}$ & $124.99 \mathrm{a}$ & $84.20 \mathrm{a}$ & $25.55 \mathrm{a}$ & $24.75 \mathrm{ab}$ \\
$\mathrm{T}_{5}$ & $11.6 \mathrm{c}$ & 6.64 & $13.22 \mathrm{a}$ & $87.33 \mathrm{a}$ & $123.36 \mathrm{a}$ & $84.83 \mathrm{a}$ & $25.31 \mathrm{ab}$ & $25.68 \mathrm{a}$ \\
$\mathrm{T}_{6}$ & $12.0 \mathrm{bc}$ & 7.31 & $13.73 \mathrm{a}$ & $86.44 \mathrm{a}$ & $121.15 \mathrm{a}$ & $87.55 \mathrm{a}$ & $25.16 \mathrm{ab}$ & $24.41 \mathrm{~b}$ \\
$\mathrm{~T}_{7}$ & $12.4 \mathrm{abc}$ & 7.56 & $14.07 \mathrm{a}$ & $89.67 \mathrm{a}$ & $124.80 \mathrm{a}$ & $84.53 \mathrm{a}$ & $25.24 \mathrm{ab}$ & $24.84 \mathrm{ab}$ \\
\hline
\end{tabular}

In a column figures having similar letter(s) do not differ significantly whereas figures with dissimilar letter(s) differ significantly as per DMRT

Table 3. Effects of nutrient sources on the filled grains panicle $e^{-1}$, grain and straw yield of first (Boro), second (T. Aman) and third (Boro) rice crops

\begin{tabular}{ccccccccc}
\hline Treatments & \multicolumn{2}{c}{$\begin{array}{c}\text { Filled grains } \\
\text { panicle }\end{array}$} & \multicolumn{3}{c}{ Straw yield(t ha ${ }^{-1}$ ) } & \multicolumn{3}{c}{ Grain yield(t ha $\left.{ }^{-1}\right)$} \\
\cline { 2 - 9 } & $\begin{array}{c}\mathbf{1}^{\text {st }} \\
\text { crop }\end{array}$ & 3 $^{\text {rd }}$ crop & $\mathbf{1}^{\text {st }}$ crop & 2 $^{\text {nd }}$ crop & 3 $^{\text {rd }}$ crop & $\mathbf{1}^{\text {st }}$ crop & $\begin{array}{c}2^{\text {nd }} \\
\text { crop }\end{array}$ & 3 $^{\text {rd }}$ crop \\
\cline { 2 - 9 } $\mathrm{T}_{0}$ & $99.7 \mathrm{~b}$ & $83 \mathrm{~b}$ & $5.63 \mathrm{c}$ & $5.201 \mathrm{~b}$ & $4.03 \mathrm{c}$ & $5.02 \mathrm{c}$ & $3.79 \mathrm{~b}$ & $3.47 \mathrm{~d}$ \\
$\mathrm{~T}_{1}$ & $130.6 \mathrm{a}$ & $107 \mathrm{a}$ & $7.01 \mathrm{~b}$ & $6.71 \mathrm{a}$ & $7.72 \mathrm{a}$ & $7.40 \mathrm{a}$ & $4.81 \mathrm{a}$ & $7.01 \mathrm{a}$ \\
$\mathrm{T}_{2}$ & $108.0 \mathrm{a}$ & $129 \mathrm{a}$ & $7.01 \mathrm{~b}$ & $6.78 \mathrm{a}$ & $6.91 \mathrm{~b}$ & $6.86 \mathrm{~b}$ & $4.71 \mathrm{a}$ & $6.40 \mathrm{abc}$ \\
$\mathrm{T}_{3}$ & $122.7 \mathrm{a}$ & $113 \mathrm{a}$ & $7.55 \mathrm{a}$ & $6.10 \mathrm{ab}$ & $7.48 \mathrm{ab}$ & $7.41 \mathrm{a}$ & $4.56 \mathrm{a}$ & $6.91 \mathrm{ab}$ \\
$\mathrm{T}_{4}$ & $123.3 \mathrm{a}$ & $121 \mathrm{a}$ & $7.23 \mathrm{ab}$ & $6.29 \mathrm{ab}$ & $6.81 \mathrm{~b}$ & $7.19 \mathrm{ab}$ & $4.48 \mathrm{a}$ & $6.21 \mathrm{c}$ \\
$\mathrm{T}_{5}$ & $122.3 \mathrm{a}$ & $116 \mathrm{a}$ & $7.14 \mathrm{ab}$ & $6.65 \mathrm{a}$ & $7.23 \mathrm{ab}$ & $7.24 \mathrm{ab}$ & $4.50 \mathrm{a}$ & $6.32 \mathrm{bc}$ \\
$\mathrm{T}_{6}$ & $114.2 \mathrm{a}$ & $129 \mathrm{a}$ & $7.01 \mathrm{~b}$ & $6.55 \mathrm{a}$ & $7.61 \mathrm{a}$ & $6.95 \mathrm{~b}$ & $4.85 \mathrm{a}$ & $6.78 \mathrm{abc}$ \\
$\mathrm{T}_{7}$ & $109.1 \mathrm{a}$ & $121 \mathrm{a}$ & $7.36 \mathrm{ab}$ & $6.48 \mathrm{a}$ & $7.25 \mathrm{ab}$ & $7.47 \mathrm{a}$ & $4.98 \mathrm{a}$ & $7.01 \mathrm{a}$ \\
\hline
\end{tabular}

In a column figures having similar letter(s) do not differ significantly whereas figures with dissimilar letter(s) differ significantly as per DMRT 


\section{Interaction effects of irrigation and fertilizer}

The highest grain yield of first crop Boro rice $\left(7.93 \mathrm{t} \mathrm{ha}^{-1}\right)$ was recorded with the treatment combination $\mathrm{I}_{1} \mathrm{~T}_{7}$ which was statistically similar to $\mathrm{I}_{1} \mathrm{~T}_{2}, \mathrm{I}_{1} \mathrm{~T}_{3}, \mathrm{I}_{2} \mathrm{~T}_{5}, \mathrm{I}_{2} \mathrm{~T}_{3}, \mathrm{I}_{2} \mathrm{~T}_{4}, \mathrm{I}_{2} \mathrm{~T}_{5}, \mathrm{I}_{3} \mathrm{~T}_{3} \mathrm{I}_{3} \mathrm{~T}_{5}$ and $\mathrm{I}_{3} \mathrm{~T}_{5}$ treatment combinations and the lowest grain yield $\left(4.48 \mathrm{t} \mathrm{ha}^{-1}\right)$ was found in $\mathrm{I}_{3} \mathrm{~T}_{0}$ treatment (Table 4). The highest grain yield of second $\left(5.34 \mathrm{t} \mathrm{ha}^{-1}\right)$ and third crops $\left(7.36 \mathrm{t} \mathrm{ha}^{-1}\right)$ were found in $\mathrm{I}_{2} \mathrm{~T}_{7}$ and $\mathrm{I}_{2} \mathrm{~T}_{7}$ treatment combinations, respectively. These results indicate that $70 \%$ nutrient from inorganic fertilizer and 30\% nutrient from poultry manure or cowdung or compost with continuous flooding or saturated condition or alternate wetting drying performed better for increasing the yield of Boro rice and similar results in the second crop T. Aman rice due to the combined application manure and fertilizer. Among the manure poultry manure performed better with different levels irrigation.

Table 4. Interaction effect of fertilizer and irrigation on the grain and straw yields of first (Boro rice), second crop (T. Aman rice) and third crop (Boro rice)

\begin{tabular}{|c|c|c|c|c|c|c|c|c|c|}
\hline Treat. & & Ist Crop & & \multicolumn{3}{|c|}{$2^{\text {nd }}$ Crop } & \multicolumn{3}{|c|}{$3^{\text {rd }}$ Crop } \\
\hline \multicolumn{10}{|c|}{ Grain yield (t ha ${ }^{-1}$ ) } \\
\hline & $\mathrm{I}_{1}$ & $\mathrm{I}_{2}$ & $\mathrm{I}_{3}$ & $I_{1}$ & $\mathrm{I}_{2}$ & $\mathrm{I}_{3}$ & $\mathrm{I}_{1}$ & $\mathrm{I}_{2}$ & $\mathrm{I}_{3}$ \\
\hline $\mathrm{T}_{0}$ & $4.91 e$ & $5.66 \mathrm{~d}$ & $4.48 e$ & 3.71 & 3.86 & 3.81 & 3.43 & 3.48 & 3.51 \\
\hline $\mathrm{T}_{1}$ & 7.51ab & 7.53ab & $7.15 b$ & 4.96 & 5.24 & 4.23 & 6.86 & 7.26 & 7.03 \\
\hline $\mathrm{T}_{2}$ & 7.32ab & $6.37 c$ & $6.90 b c$ & 4.66 & 4.89 & 4.59 & 6.78 & 5.82 & 6.60 \\
\hline $\mathrm{T}_{3}$ & 7.32ab & $7.42 \mathrm{ab}$ & $7.50 \mathrm{ab}$ & 4.25 & 4.46 & 4.97 & 7.29 & 6.69 & 6.75 \\
\hline $\mathrm{T}_{4}$ & 7.30ab & 7.27ab & $7.00 \mathrm{bc}$ & 4.19 & 4.46 & 4.78 & 6.55 & 6.40 & 5.67 \\
\hline $\mathrm{T}_{5}$ & $7.18 b$ & 7.32ab & 7.21ab & 4.01 & 4.96 & 4.52 & 6.31 & 6.30 & 6.35 \\
\hline $\mathrm{T}_{6}$ & $7.04 b c$ & $6.90 b c$ & $6.91 b c$ & 4.16 & 5.23 & 5.15 & 6.53 & 6.36 & 6.23 \\
\hline $\mathrm{T}_{7}$ & 7.93a & $7.08 \mathrm{bc}$ & $7.40 \mathrm{ab}$ & 5.04 & 5.34 & 4.55 & 7.31 & 6.06 & 7.36 \\
\hline \multicolumn{10}{|c|}{ Straw yield $\left(\mathrm{t} \mathrm{ha}^{-\mathbf{1}}\right)$} \\
\hline $\mathrm{T}_{0}$ & 5.57 & 6.33 & 4.97 & 5.00 & 5.15 & 5.46 & 5.57 & 6.33 & 4.97 \\
\hline $\mathrm{T}_{1}$ & 7.37 & 6.94 & 6.71 & 6.75 & 6.78 & 6.59 & 7.37 & 6.94 & 6.71 \\
\hline $\mathrm{T}_{2}$ & 7.23 & 6.70 & 7.10 & 5.56 & 7.00 & 7.35 & 7.23 & 6.70 & 7.10 \\
\hline $\mathrm{T}_{3}$ & 7.32 & 7.74 & 7.58 & 5.78 & 6.23 & 6.28 & 7.32 & 7.74 & 7.58 \\
\hline $\mathrm{T}_{4}$ & 7.27 & 7.18 & 7.24 & 6.01 & 6.24 & 6.61 & 7.27 & 7.18 & 7.24 \\
\hline $\mathrm{T}_{5}$ & 7.08 & 7.18 & 7.15 & 6.23 & 6.55 & 7.17 & 7.08 & 7.18 & 7.15 \\
\hline $\mathrm{T}_{6}$ & 7.04 & 7.13 & 6.88 & 6.19 & 6.86 & 6.58 & 7.04 & 7.13 & 6.88 \\
\hline $\mathrm{T}_{7}$ & 7.65 & 7.46 & 6.96 & 6.32 & 7.40 & 6.10 & 7.65 & 7.46 & 6.96 \\
\hline
\end{tabular}

In a column figures having similar letter(s) do not differ significantly whereas figures with dissimilar letter(s) differ significantly as per DMRT

The combined effects of different doses of fertilizer and irrigation on the grain and straw yield of rice were not significantly different. The $100 \% \mathrm{RDCF}$ was applied in all the treatments during $\mathrm{T}$. Aman rice cultivation except control treatment but yields were significantly affected due to the application of different types of fertilizer and manure treatments in the previous Boro rice cultivation. Higher T. Aman rice yields (second crop) were obtained in organic plus inorganic fertilizer treatments with different levels of irrigation due to residual effects of fertilizer and manure which was applied in previous Boro rice cultivation.

The highest straw yield $\left(7.74 \mathrm{t} \mathrm{ha}^{-1}\right)$ of third crop was obtained from $\mathrm{I}_{2} \mathrm{~T}_{3}$ treatment combination. The highest grain yield of third crop $\left(7.36 \mathrm{t} \mathrm{ha}^{-1}\right)$ was recorded with the treatment combination $\mathrm{I}_{3} \mathrm{~T}_{7}$ which was similar to $\mathrm{I}_{1} \mathrm{~T}_{7}\left(7.31 \mathrm{t} \mathrm{ha}^{-1}\right), \mathrm{I}_{1} \mathrm{~T}_{3}\left(7.29 \mathrm{t} \mathrm{ha} \mathrm{a}^{-1}\right)$ and $\mathrm{I}_{2} \mathrm{~T}_{1}\left(7.26 \mathrm{tha} \mathrm{a}^{-1}\right)$ 
treatment combinations. The lowest grain yield $\left(3.43 \mathrm{t}\right.$ ha $\left.{ }^{-1}\right)$ was found in $\mathrm{I}_{1} \mathrm{~T}_{0}$ treatment combination. This result indicated that $70 \%$ nutrient from inorganic source and $30 \%$ nutrient from poultry manure with the application of alternate wetting and drying performed better for increasing the Boro rice yield. Rahman et al. (2019) and Islam et al. (2013) found similar results by using manure and fertilizer in rice with different levels of irrigation.

Effects of irrigation, fertilizer and manure on the growth and yield of fourth crop T. Aman rice

The results showed that the yield and yield parameters of T. Aman rice were not significantly influenced by irrigation but significantly influenced by residual effects of fertilizer and manure application (Table 5). Among the different fertilizer treatments, $\mathrm{T}_{6}$ showed the highest plant height $(123.2 \mathrm{~cm})$. The maximum panicle length $(25.26 \mathrm{~cm})$, filled grains panicle ${ }^{-1}(88.1)$ and 1000 seed weight $(21.22 \mathrm{~g})$ were found in the $T_{5}, T_{3}$ and $T_{7}$ treatments respectively and the lowest plant height, number of effective tillers hill ${ }^{-1}$, filled grains panicle $e^{-1}$ were observed in $T_{0}$ treatment.

The application of fertilizers plus manure in the previous rice crops had a positive and significant effect on the grain and straw yield of $\mathrm{T}$. Aman rice (Table 5). The highest straw yield (6.26 $\left.t \mathrm{ha}^{-1}\right)$ was obtained due to the residual effect of $T_{5}$ treatment which was statistically similar to all other treatments except $\mathrm{T}_{0}$.

Table 5. Effect of fertilizer and manure on the yield parameters and yield of fourth crop T. Aman rice

\begin{tabular}{|c|c|c|c|c|c|c|}
\hline Treatments & $\begin{array}{l}\text { Plant } \\
\text { height } \\
(\mathrm{cm})\end{array}$ & $\begin{array}{c}\text { Panicle } \\
\text { length } \\
\text { (cm) }\end{array}$ & $\begin{array}{c}\text { Number of } \\
\text { filled grains } \\
\text { panicle }^{-1}\end{array}$ & $\begin{array}{c}1000- \\
\text { grainweight(g) }\end{array}$ & $\begin{array}{c}\text { Straw yield } \\
\left(\mathrm{t} \mathrm{ha} \mathrm{h}^{-1}\right)\end{array}$ & $\begin{array}{c}\text { Grain } \\
\text { yield } \\
\left(\mathrm{t} \mathrm{ha}^{-1}\right)\end{array}$ \\
\hline $\mathrm{T}_{0}$ & $104.9 b$ & $21.78 \mathrm{c}$ & $68.37 b$ & $19.56 \mathrm{c}$ & $4.42 b$ & $3.47 \mathrm{~b}$ \\
\hline $\mathrm{T}_{1}$ & $118.6 a$ & $24.46 \mathrm{ab}$ & $85.42 \mathrm{a}$ & $20.78 \mathrm{ab}$ & $6.03 a$ & $4.34 a$ \\
\hline $\mathrm{T}_{2}$ & $120.7 \mathrm{a}$ & $24.46 \mathrm{ab}$ & $87.93 a$ & $20.22 b c$ & $5.78 \mathrm{a}$ & $4.48 a$ \\
\hline $\mathrm{T}_{3}$ & $120.8 \mathrm{a}$ & $24.77 \mathrm{ab}$ & $88.09 a$ & $20.44 a b c$ & $6.02 \mathrm{a}$ & $4.40 \mathrm{a}$ \\
\hline $\mathrm{T}_{4}$ & $119.9 a$ & $23.99 b$ & $83.69 a$ & $21.11 \mathrm{ab}$ & $5.94 a$ & $4.32 \mathrm{a}$ \\
\hline $\mathrm{T}_{5}$ & $118.9 a$ & $25.26 a$ & $84.71 \mathrm{a}$ & $21.00 \mathrm{ab}$ & $6.26 a$ & $4.09 a$ \\
\hline$T_{6}$ & $123.2 \mathrm{a}$ & $24.29 b$ & $84.77 a$ & 20.89ab & $5.82 \mathrm{a}$ & $4.07 a$ \\
\hline $\mathrm{T}_{7}$ & $119.3 a$ & 24.36ab & $78.84 a$ & $21.22 \mathrm{a}$ & $5.92 \mathrm{a}$ & $4.18 \mathrm{a}$ \\
\hline
\end{tabular}

In a column figures having similar letter(s) do not differ significantly whereas figures with dissimilar letter(s) differ significantly as per DMRT

The highest grain yield $\left(4.48 \mathrm{tha}^{-1}\right)$ was observed in the $\mathrm{T}_{2}$ treatment in Boro rice crops which was statistically similar to all other treatment except $T_{0}$ (control). This result indicates that $T$. Aman rice yield was increased more due to the residual effects of fertilizer plus manure treatments which were applied during previous Boro rice cropping. The lowest grain yield (3.79 $\mathrm{tha}^{-1}$ ) was observed with $\mathrm{T}_{0}$ where no fertilizer was applied.

Interaction effects of fertilizer and manure on the grain and straw yield of fourth crop T. Aman rice

Plant height, panicle length, number of filled grains panicle $e^{-1}, 1000$ seed weight were not significantly influenced by interaction effect of irrigation and fertilizer. The grain and straw yields were significantly influenced by irrigation and fertilizer treatments. The highest straw yield (7.21 $t$ ha ${ }^{-1}$ ) was found in $I_{1} T_{5}$ treatment combination which was statistically similar to $I_{1} T_{7}, I_{2} T_{1}, I_{2} T_{2}$, 
$\mathrm{I}_{2} \mathrm{~T}_{3}$ treatment combinations. The highest grain yield of $5.35 \mathrm{t}$ ha ${ }^{-1}$ was recorded in $\mathrm{I}_{2} \mathrm{~T}_{2}$ treatment combination which was statistically comparable to $\mathrm{I}_{1} \mathrm{~T}_{5}, \mathrm{I}_{1} \mathrm{~T}_{7}, \mathrm{I}_{2} \mathrm{~T}_{1}, \mathrm{I}_{2} \mathrm{~T}_{3}$ and $\mathrm{I}_{3} \mathrm{~T}_{4}$.

Table 6. Effect of irrigation and fertilizer and manure on the grain and straw yield of fourth crop (T. Aman rice )

\begin{tabular}{ccccccc}
\hline Treat. & \multicolumn{3}{c}{${\left.\text { Grain Yield (t ha }{ }^{-1}\right)}$} & \multicolumn{3}{c}{ Straw yield (t ha-1) } \\
\hline & $\mathrm{I}_{1}$ & $\mathrm{I}_{2}$ & $\mathrm{I}_{3}$ & $\mathrm{I}_{1}$ & $\mathrm{I}_{2}$ & $\mathrm{I}_{3}$ \\
\cline { 2 - 6 } $\mathrm{T}_{0}$ & $3.35 \mathrm{~h}$ & $3.58 \mathrm{fgh}$ & $3.47 \mathrm{gh}$ & $4.45 \mathrm{fg}$ & $4.65 \mathrm{efg}$ & $4.16 \mathrm{~g}$ \\
$\mathrm{~T}_{1}$ & $3.96 \mathrm{~d}-\mathrm{h}$ & $4.87 \mathrm{abc}$ & $4.21 \mathrm{c}-\mathrm{g}$ & $5.71 \mathrm{~b}-\mathrm{f}$ & $6.65 \mathrm{a}-\mathrm{d}$ & $5.75 \mathrm{a}-\mathrm{f}$ \\
$\mathrm{T}_{2}$ & $3.97 \mathrm{~d}-\mathrm{h}$ & $5.35 \mathrm{a}$ & $4.13 \mathrm{c}-\mathrm{h}$ & $5.28 \mathrm{c}-\mathrm{g}$ & $6.88 \mathrm{ab}$ & $5.20 \mathrm{~d}-\mathrm{g}$ \\
$\mathrm{T}_{3}$ & $3.80 \mathrm{~d}-\mathrm{h}$ & $5.09 \mathrm{ab}$ & $4.31 \mathrm{~b}-\mathrm{f}$ & $5.51 \mathrm{~b}-\mathrm{g}$ & $6.70 \mathrm{abc}$ & $5.84 \mathrm{a}-\mathrm{f}$ \\
$\mathrm{T}_{4}$ & $4.37 \mathrm{~b}-\mathrm{f}$ & $4.02 \mathrm{~d}-\mathrm{h}$ & $4.56 \mathrm{a}-\mathrm{d}$ & $5.61 \mathrm{~b}-\mathrm{g}$ & $5.79 \mathrm{a}-\mathrm{e}$ & $6.42 \mathrm{a}-\mathrm{d}$ \\
$\mathrm{T}_{5}$ & $4.84 \mathrm{abc}$ & $3.67 \mathrm{e}-\mathrm{h}$ & $3.77 \mathrm{~d}-\mathrm{h}$ & $7.21 \mathrm{a}$ & $5.90 \mathrm{a}-\mathrm{e}$ & $5.67 \mathrm{~b}-\mathrm{f}$ \\
$\mathrm{T}_{6}$ & $3.90 \mathrm{~d}-\mathrm{h}$ & $3.91 \mathrm{~d}-\mathrm{h}$ & $4.42 \mathrm{~b}-\mathrm{e}$ & $5.34 \mathrm{c}-\mathrm{g}$ & $6.13 \mathrm{a}-\mathrm{d}$ & $6.00 \mathrm{a}-\mathrm{e}$ \\
$\mathrm{T}_{7}$ & $4.56 \mathrm{a}-\mathrm{d}$ & $4.11 \mathrm{c}-\mathrm{h}$ & $3.89 \mathrm{~d}-\mathrm{h}$ & $6.72 \mathrm{abc}$ & $5.63 \mathrm{~b}-\mathrm{f}$ & $5.42 \mathrm{~b}-\mathrm{g}$ \\
\hline
\end{tabular}

In a column figures having similar letter(s) do not differ significantly whereas figures with dissimilar letter(s) differ significantly as per DMRT

These results indicate that $T$. Aman rice yield was increased due to the interaction of effects of fertilizer and reduced irrigation treatments where fertilizer, manure were applied combined with reduced level of irrigation during previous Boro rice cropping (Table 6).

\section{Individual Effects of Irrigation and Fertilizer on Growth, Yield of fifth crop Boro Rice}

The number of effective tillers hill ${ }^{-1}$, plant height, filled grains panicle ${ }^{-1}$, grain yield were not significantly affected by irrigation but panicle length and straw yields were affected significantly (Table 7). The highest number of effective tillers hill-1 ${ }^{-1}$ (13.64), were found in continuous flooded condition which was closely similar to (13.58) in alternate wetting and drying irrigation. The highest panicle length $(22.29 \mathrm{~cm})$ and straw yield $\left(7.51 \mathrm{t} \mathrm{ha}^{-1}\right)$ were found in $\mathrm{I}_{1}$ and lower and statistically similar panicle length and straw yield were recorded in $\mathrm{I}_{2}$ and $\mathrm{I}_{3}$ treatments. The highest grain yield $\left(7.11 \mathrm{t} \mathrm{ha}^{-1}\right)$ was found in $\mathrm{I}_{1}$ treatment which was closely similar to saturated irrigation $\left(6.98 \mathrm{t} \mathrm{ha}^{-1}\right)$ and the lowest $\left(6.87 \mathrm{t} \mathrm{ha}^{-1}\right)$ in $\mathrm{I}_{3}$.

Table 7. Effect of irrigation on the growth and yield parameter of fifth crop Boro rice

\begin{tabular}{ccccccc}
\hline Treatments & $\begin{array}{c}\text { Number of } \\
\text { effective } \\
\text { tillershill }^{-1}\end{array}$ & $\begin{array}{c}\text { Plant } \\
\text { height } \\
(\mathbf{c m})\end{array}$ & $\begin{array}{c}\text { Panicle } \\
\text { length } \\
(\mathbf{c m})\end{array}$ & $\begin{array}{c}\text { Number of } \\
\text { filled } \\
\text { grainspanicle }^{-1}\end{array}$ & $\begin{array}{c}\text { Straw } \\
\text { yield } \\
\left(\mathbf{t ~ h a}^{-1}\right)\end{array}$ & $\begin{array}{c}\text { Grain } \\
\text { yield } \\
\text { (t ha }^{-1} \text { ) }\end{array}$ \\
\hline $\mathrm{I}_{1}$ & 13.64 & 77.40 & $22.29 \mathrm{~b}$ & 93.48 & $7.51 \mathrm{~b}$ & 7.11 \\
$\mathrm{I}_{2}$ & 13.18 & 76.82 & $21.62 \mathrm{a}$ & 98.23 & $7.22 \mathrm{a}$ & 6.98 \\
$\mathrm{I}_{3}$ & 13.58 & 76.36 & $21.75 \mathrm{a}$ & 98.42 & $7.24 \mathrm{a}$ & 6.87 \\
\hline
\end{tabular}

$\mathrm{I}_{1}=$ Continuous flooded; $\mathrm{I}_{2}=$ Saturated condition; $\mathrm{I}_{3}=$ Alternate wetting and drying

In a column figures having similar letter(s) do not differ significantly whereas figures with dissimilar letter(s) differ significantly as per DMRT 
The number of effective tillers hill ${ }^{-1}$, panicle length, filled grains panicle ${ }^{-1}$, straw and grain yield were significantly affected by application of different fertilizer and manure (Table 8). The highest number of effective tillers hill ${ }^{-1}$ (14.4) was found in $T_{1}$ treatment which was statistically similar to all other treatments except $\mathrm{T}_{0}$ (control). The higher plant height, panicle lengths, filled grains panicle ${ }^{-1}$ were found in organic plus inorganic treatments and lowest values were observed in $\mathrm{T}_{0}$ treatment. The highest panicle length $(22.50 \mathrm{~cm})$, filled grains panicle $e^{-1}(108.5)$ were found in $T_{6}$ where filled grains panicle ${ }^{-1}$ was statistically similar to $T_{4}, T_{7}, T_{3}, T_{5}$ and $T_{1}$ treatments.

Table 8. Effects of fertilizer and manure on the yield parameters and yield of fifth crop Boro rice

\begin{tabular}{ccccccc}
\hline Treatments & $\begin{array}{c}\text { No. } \\
\text { effective } \\
\text { tillers hill } \mathbf{1}\end{array}$ & $\begin{array}{c}\text { Plant } \\
\text { height } \\
(\mathbf{c m})\end{array}$ & $\begin{array}{c}\text { Panicle } \\
\text { length } \\
\text { (cm) }\end{array}$ & $\begin{array}{c}\text { No. of filled } \\
\text { grains } \\
\text { panicle } \mathbf{- 1}\end{array}$ & $\begin{array}{c}\text { Straw } \\
\text { yield } \\
\text { ( ha }^{-1} \text { ) }\end{array}$ & $\begin{array}{c}\text { Grain yield } \\
\text { (t ha }^{-1} \text { ) }\end{array}$ \\
\hline $\mathrm{T}_{0}$ & $10.80 \mathrm{~b}$ & 70.91 & $20.53 \mathrm{~b}$ & $78.3 \mathrm{c}$ & $5.70 . \mathrm{b}$ & $5.42 \mathrm{e}$ \\
$\mathrm{T}_{1}$ & $14.36 \mathrm{a}$ & 78.31 & $22.30 \mathrm{a}$ & $94.4 \mathrm{abc}$ & $7.78 \mathrm{a}$ & $7.03 \mathrm{~cd}$ \\
$\mathrm{~T}_{2}$ & $14.09 \mathrm{a}$ & 78.37 & $22.28 \mathrm{a}$ & $90.1 \mathrm{bc}$ & $7.39 \mathrm{a}$ & $7.07 \mathrm{bcd}$ \\
$\mathrm{T}_{3}$ & $13.53 \mathrm{a}$ & 76.13 & $21.64 \mathrm{ab}$ & $100.8 \mathrm{ab}$ & $7.66 \mathrm{a}$ & $7.37 \mathrm{abc}$ \\
$\mathrm{T}_{4}$ & $13.40 \mathrm{a}$ & 76.69 & $21.95 \mathrm{a}$ & $103.2 \mathrm{ab}$ & $7.35 \mathrm{a}$ & $7.19 \mathrm{bc}$ \\
$\mathrm{T}_{5}$ & $14.07 \mathrm{a}$ & 79.02 & $22.01 \mathrm{a}$ & $95.7 \mathrm{abc}$ & $7.48 \mathrm{a}$ & $6.74 \mathrm{~d}$ \\
$\mathrm{~T}_{6}$ & $13.62 \mathrm{a}$ & 78.21 & $22.50 \mathrm{a}$ & $108.5 \mathrm{a}$ & $7.49 \mathrm{a}$ & $7.40 \mathrm{ab}$ \\
$\mathrm{T}_{7}$ & $13.87 \mathrm{a}$ & 77.22 & $21.87 \mathrm{a}$ & $102.5 \mathrm{ab}$ & $7.71 \mathrm{a}$ & $7.70 \mathrm{a}$ \\
\hline
\end{tabular}

In a column figures having similar letter(s) do not differ significantly at $5 \%$ level whereas figures with dissimilar letter(s) differ significantly as per DMRT

The application of fertilizers and manure had a positive and significant effect on the grain and straw yield of Boro rice (Table 8). The highest straw yield $\left(7.78 \mathrm{t} \mathrm{ha}^{-1}\right)$ was obtained in $\mathrm{T}_{1}$ (RDCF) treatment which was statistically similar to all other treatments except control. The highest grain yield $\left(7.70 \mathrm{t} \mathrm{ha}^{-1}\right)$ was observed in the $\mathrm{T}_{7}$ treatment which was statistically similar to $\mathrm{T}_{6}$ treatments and lowest grain yield $\left(5.02 \mathrm{t} \mathrm{ha}^{-1}\right)$ was observed in $\mathrm{T}_{0}$ treatment. This result indicates that application of 70\% nutrient as inorganic fertilizer and 30\% nutrient from organic sources increased the yield and yield contributing parameters of Boro rice.

\section{Interaction Effects of Irrigation and Fertilizer on the Growth and Yield of fifth crop Boro rice}

The numbers of effective tillers hill ${ }^{-1}$, panicle length and straw yield were not significantly influenced by combined effects of irrigation and fertilizer. The maximum plant height $(81.60 \mathrm{~cm})$ and filled grains panicle $e^{-1}(119.60 \mathrm{~cm})$ were obtained from $\mathrm{I}_{1} \mathrm{~T}_{3}$ which was closely similar to $\mathrm{I}_{1} \mathrm{~T}_{7}, \mathrm{I}_{3} \mathrm{~T}_{6}, \mathrm{I}_{3} \mathrm{~T}_{7}$ and lowest was recorded in $\mathrm{I}_{1} \mathrm{~T}_{0}$ treatment combination (Table 9). The highest grain yield of rice $\left(7.94 \mathrm{t} \mathrm{ha}^{-1}\right)$ was recorded with the treatment combination $\mathrm{I}_{1} \mathrm{~T}_{7}$ which was statistically similar to $\mathrm{I}_{1} \mathrm{~T}_{3}\left(7.73 \mathrm{t} \mathrm{ha}^{-1}\right), \mathrm{I}_{1} \mathrm{~T}_{6}\left(7.72 \mathrm{t} \mathrm{ha}^{-1}\right), \mathrm{I}_{3} \mathrm{~T}_{7}(7.62 \mathrm{t} \mathrm{ha}-1), \mathrm{I}_{1} \mathrm{~T}_{4}\left(7.60 \mathrm{t} \mathrm{ha}^{-1}\right)$ and $\mathrm{I}_{3} \mathrm{~T}_{6}\left(7.55 \mathrm{t} \mathrm{ha}^{-1}\right)$ treatment combinations and the lowest grain yield $\left(5.26 \mathrm{t} \mathrm{ha}^{-1}\right)$ was found in $\mathrm{I}_{2} \mathrm{~T}_{0}$ treatment combination. The results also indicate that $70 \%$ nutrient from inorganic sources plus 30\% nutrient from poultry manure or cowdung with continuous flooded $\left(\mathrm{I}_{1}\right)$ or alternate wetting and drying $\left(\mathrm{I}_{3}\right)$ condition produced better yield of Boro rice. The best yield performance was obtained from $\mathrm{I}_{1} \mathrm{~T}_{7}$ treatment combinations followed by $\mathrm{I}_{1} \mathrm{~T}_{3}$. Lin et al. (2011) reported that reduced irrigation with organic material application increased yield of rice. 
Table 9. Interaction effect of fertilizer and irrigation on Plant height, filled grains/panicle and grain yield of fifth crop Boro rice

\begin{tabular}{|c|c|c|c|c|c|c|c|c|c|}
\hline \multirow[t]{2}{*}{ Treat. } & \multicolumn{3}{|c|}{$\begin{array}{l}\text { Plant height } \\
\text { (cm) }\end{array}$} & \multicolumn{3}{|c|}{$\begin{array}{l}\text { No. of filled grains } \\
\text { panicle }{ }^{-1}\end{array}$} & \multicolumn{3}{|c|}{$\begin{array}{l}\text { Grain yield } \\
\left(\mathrm{t} \mathrm{ha}^{-1}\right)\end{array}$} \\
\hline & $\mathrm{I}_{1}$ & $\mathrm{I}_{2}$ & $\mathrm{I}_{3}$ & $I_{1}$ & $\mathrm{I}_{2}$ & $I_{3}$ & $I_{1}$ & $\mathrm{I}_{2}$ & $I_{3}$ \\
\hline $\mathrm{T}_{0}$ & 69.73h & $2.43 \mathrm{fgh}$ & $0.58 \mathrm{gh}$ & $70.4 \mathrm{~g}$ & 30.8 efg & $3.8 \mathrm{c}$ & $5.60 \mathrm{i}$ & $5.26 \mathrm{i}$ & $5.38 \mathrm{i}$ \\
\hline $\mathrm{T}_{1}$ & 78.78a-d & 7.63a-e & 78.53a-d & $74.3 \mathrm{fg}$ & $111.4 \mathrm{a}-\mathrm{d}$ & 97.6a-g & 6.71gh & 50a-e & $6.87 \mathrm{fgh}$ \\
\hline $\mathrm{T}_{2}$ & 77.60a-e & 77.62a-e & 79.88abc & $82.6 \mathrm{~d}-\mathrm{g}$ & $85.1 \mathrm{~b}-\mathrm{g}$ & $102.7 \mathrm{a}-\mathrm{f}$ & $7.08 c-h$ & $9 d-h$ & 7.15b-h \\
\hline $\mathrm{T}_{3}$ & $81.60 \mathrm{a}$ & $74.20 \mathrm{~d}-\mathrm{h}$ & $72.58 e-h$ & $119.6 a$ & $97.8 \mathrm{a}-\mathrm{g}$ & $1 b-g$ & 7.73ab & $b-g$ & $7.22 \mathrm{~b}-\mathrm{g}$ \\
\hline $\mathrm{T}_{4}$ & 2a-e & $1 \mathrm{a}-\mathrm{f}$ & & $96.5 \mathrm{a}-\mathrm{g}$ & $112.8 \mathrm{abc}$ & $100.4 a-f$ & 7.60abc & & $6.56 \mathrm{~h}$ \\
\hline $\mathrm{T}_{5}$ & 79.43abc & $81.60 \mathrm{a}$ & 75.96b-f & $86.1 \mathrm{~b}-\mathrm{g}$ & 103.8a-f & $97.4 \mathrm{a}-\mathrm{g}$ & $5.77 \mathrm{i}$ & tb-h & $7.30 \mathrm{~b}-\mathrm{g}$ \\
\hline $\mathrm{T}_{6}$ & 75.98b-f & 77.87a-d & $80.78 \mathrm{ab}$ & 108.0a-e & 103.8a-f & 113.7ab & 7.72ab & $6.93 e-h$ & 7.55a-d \\
\hline $\mathrm{T}_{7}$ & 78.47a-d & 75.83b-f & 77.36a-f & 110.5a-e & 90.3a-g & 106.6a-e & $7.94 \mathrm{~g}$ & 7.53a-d & $7.62 \mathrm{abc}$ \\
\hline
\end{tabular}

In a column figures having similar letter(s) do not differ significantly whereas figures with dissimilar letter(s) differ significantly as per DMRT

\section{Effect of irrigation, fertilizer and manure on the nutrient concentration and chemical properties of post-harvest field soil}

The application of manure and fertilizer in the Boro seasons influenced the OM content in soil. The lower level of OM matter was found in the post-harvest soils of $T_{0}$ (control) and $T_{1}$ (RDCF) treatments. The increasing levels of $\mathrm{OM}$ were almost similar in all the treatments where manure plus inorganic fertilizer were used. Similarly, higher levels of available $P$ were found in the $T_{2}-T_{7}$ treatments where organic plus inorganic fertilizers were used. The highest concentration $P$ was found in the $\mathrm{T}_{7}$ treatment where $70 \% \mathrm{RDCF}+2.1$ ton poultry manure ha-1 used. The level of soil $\mathrm{N}$ and $\mathrm{K}$ concentrations were increased more where inorganic and organic fertilizers were used. The highest $\mathrm{K}$ concentration was found in $\mathrm{T}_{5}$ treatment where $70 \%$ inorganic fertilizer and 3 ton ha ${ }^{-1}$ water hyacinth compost were used. The $\mathrm{pH}$ of post-harvest soils increased in $\mathrm{T}_{6}$ and $\mathrm{T}_{7}$ treatments where poultry manure was applied in combination with fertilizer (Table 10). The soil organic matter, $\mathrm{pH}$ and nutrient levels were not significantly affected by interaction effects of irrigation and fertilizer treatments.

Table 10. Effect of fertilizer and manure on the nutrient concentration and chemical properties of post-experiment soil

\begin{tabular}{cccccc}
\hline Treatments & Soil $\mathbf{p H}$ & $\begin{array}{c}\text { Soil organic } \\
\text { matter (\%) }\end{array}$ & $\begin{array}{c}\text { Total } \mathbf{N} \\
(\mathbf{\%})\end{array}$ & $\begin{array}{c}\text { Available } \mathbf{P} \\
(\mathbf{p p m})\end{array}$ & $\begin{array}{c}\text { Available } \mathrm{K} \\
\text { (ppm) }\end{array}$ \\
\hline $\mathrm{T}_{0}$ & $6.6 \mathrm{~b}$ & $1.08 \mathrm{c}$ & 0.079 & $11.23 \mathrm{~d}$ & $19.56 \mathrm{c}$ \\
$\mathrm{T}_{1}$ & $6.6 \mathrm{~b}$ & $1.15 \mathrm{bc}$ & 0.088 & $13.62 \mathrm{c}$ & $28.33 \mathrm{ab}$ \\
$\mathrm{T}_{2}$ & $6.6 \mathrm{~b}$ & $1.33 \mathrm{a}$ & 0.096 & $15.80 \mathrm{abc}$ & $29.44 \mathrm{ab}$ \\
$\mathrm{T}_{3}$ & $6.6 \mathrm{~b}$ & $1.32 \mathrm{a}$ & 0.096 & $13.82 \mathrm{c}$ & $27.33 \mathrm{~b}$ \\
$\mathrm{~T}_{4}$ & $6.6 \mathrm{~b}$ & $1.29 \mathrm{a}$ & 0.092 & $14.26 \mathrm{bc}$ & $30.11 \mathrm{ab}$ \\
$\mathrm{T}_{5}$ & $6.5 \mathrm{~b}$ & $1.33 \mathrm{a}$ & 0.102 & $15.21 \mathrm{abc}$ & $31.94 \mathrm{a}$ \\
$\mathrm{T}_{6}$ & $6.9 \mathrm{a}$ & $1.31 \mathrm{a}$ & 0.089 & $16.50 \mathrm{ab}$ & $28.44 \mathrm{ab}$ \\
$\mathrm{T}_{7}$ & $6.7 \mathrm{ab}$ & $1.27 \mathrm{ab}$ & 0.090 & $16.59 \mathrm{a}$ & $29.61 \mathrm{ab}$ \\
\hline
\end{tabular}

\section{Conclusion}

The growth and yield of rice crops were not significantly affected by irrigation but higher yields were obtained in continuous flooded irrigation. The higher Boro rice yields were found from the treatments where 70\% nutrient from inorganic fertilizer and 30\% nutrients from organic sources 
were applied. The poultry manure performed better compared to compost and cowdung for increasing the yield of Boro rice. The maxinum grain yield of Boro rice was recorded with the treatment combination $\mathrm{I}_{1} \mathrm{~T}_{7}$ (continuous flooding $+70 \% \mathrm{RDCF}+2.1$ ton poultry manure ha ${ }^{-1}$ ) followed by $\mathrm{I}_{3} \mathrm{~T}_{7}$ (Alternate wetting and drying $+70 \% \mathrm{RDCF}+2.1$ ton poultry manure ha-1) treatment combination. T. Aman rice yields were significantly influenced due to the residual effects of applied fertilizer plus manure treatments during previous Boro cropping. Higher $\mathrm{T}$. Aman rice yields were obtained in $\mathrm{I}_{2} \mathrm{~T}_{7}$ (saturated condition $+70 \% \mathrm{RDCF}+2.1$ ton poultry manure ha ${ }^{-1}$ ) or $\mathrm{I}_{1} \mathrm{~T}_{7}$ (continuous flooded $+70 \% \mathrm{RDCF}+2.1$ ton poultry manure ha-1) treatment combinations. The level of soil organic matter, N, P and $\mathrm{K}$ concentrations increased in the treatments where manure plus inorganic fertilizers were used. The application of poultry manure increased the $\mathrm{pH}$ of the soil.

\section{Acknowledgement}

The authors gratefully acknowledge the financial support from core research grants of Bangladesh Agricultural Research Council.

\section{References}

Bari, A.S.M.F., M.A. Khan and S. Sultana. 2013. Effect of various inorganic fertilizer and manure applications with different water managements on yield and yield attributes of boro rice. J. Expt. Biosci. 4(2): 1-6.

Bremner, J.M. and C.S. Mulvancy. 1982. In: A.L. Page et al. (ed.) Methods of Soil Analysis, Part 2,23 Amer. Soc. Agron. Inc, Madi, Wis.

FAO (Food and Agriculture Organization). 1999. Yearbook of Production, FAO Statistics Division. pp.605-607.

Islam, M.M.A.F., M.A. Khan and A.S.M.F. Bari. 2013. Effect of fertilizer and manure with different water management on the growth, yield and quality of Boro rice. The Agriculturist 11(2): 4451.

Ishaque, M., G.M. Panaullah, N. Bhuyian and P.K. Saha. 1998. Integrated nutrient management with inorganic fertilizer and green/organic manures for boro-T. aman rice cropping pattern. In proceedings "National Workshop on Integrated Nutrient Management for Crop Production and Soil Fertility" held on 24-25 March, 1998 at BARI, Gazipur, Bangladesh. pp.111-114.

McLean, E.O. 1982. Soil pH and lime requirement. In: Methods of soil analysis, Part 2, Chemical and microbiological properties, A. L. Page,(eds.), Amer. Soc. of Agro. Inc., Madison, WI, USA. pp.199-224.

Rahman, M.M., M.A. Khan, A.K. Paul and M.A. Haque.2019. Effect of fertilizer, manure and irrigation on nutrient availability in soil of boro rice field. Euras. J. Soil Sci. 8(4):282-288.

Olsen, S.R. and L.E. Sommers. 1982. In: A.L. Page et al. (ed.) Methods of Soil Analysis, Part 2,2 Amer. Soc. of Agron. Inc, Madi, Wis.

Page, A.L., R.H. Miller and D.R. Keeney. 1982. Methods of analysis part 2, Chemical and Microbiological Properties, Second Edition American Society of Agronomy, Inc., Soil Sci. Soc. of Amer. Inc. Madison, Wisconsin, USA. pp.403-430.

UNDP and FAO. 1988. Land Resources Appraisal of Bangladesh for Agricultural Report No. 2. Agro-Ecological Region of Bangladesh. United Nations Development Program in Food and Agriculture Organization, 212-221. 
Walkley, A. and D.R. Black. 1975. An examination of the digestion method for determining soil organic matter and proposed modification of the chronic acid titration method. Soil Sci. 37: 29-38.

Xiangin, L., D. Zhu and Xinjunlin. 2011. Effects of water management and organic fertilization with SRI crop practices on hybrid rice performance and rhizosphere dynamics. Paddy Water Environ. 9: 33-39.

Xu, M.G., D.C. Li, J.M. Li, D.Z. Qin, Yagikazuyuki and Y. Hosen. 2008. Effects of organic manure application with chemical fertilizers or nutrient absorption and yield of rice in Hunan of Southern China. Agric. Sci. China 7(10): 1245-1252.

Yang, C.M., L. Yang, Y. Yang and Z. Ouyang. 2004. Rice root growth and nutrient uptake as influenced by organic manure in continuously and alternately flooded paddy soils. Agric. Water Mng. 70(1): 67-81. 